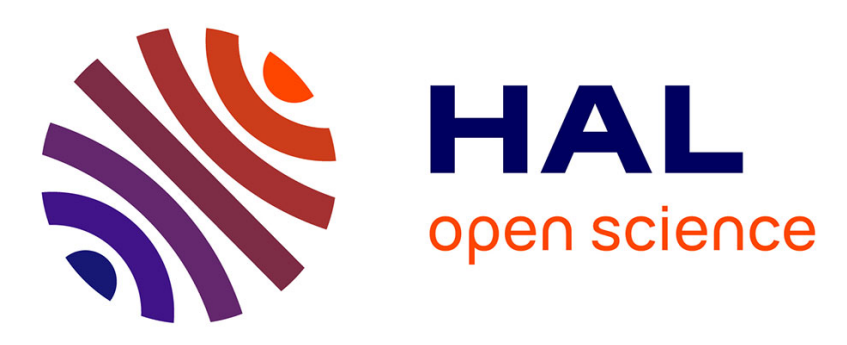

\title{
Comment on "N-terminal Protein Tail Acts as Aggregation Protective Entropic Bristles: The SUMO Case"
}

Magalie Sénéchal, Jennifer Bouchenna, Jérôme Vicogne, Oleg Melnyk

\section{- To cite this version:}

Magalie Sénéchal, Jennifer Bouchenna, Jérôme Vicogne, Oleg Melnyk. Comment on "N-terminal Protein Tail Acts as Aggregation Protective Entropic Bristles: The SUMO Case". Biomacromolecules, 2020, 21 (8), pp.3480-3482. 10.1021/acs.biomac.0c00185 . hal-02995257

\section{HAL Id: hal-02995257 \\ https://hal.science/hal-02995257}

Submitted on 13 Nov 2020

HAL is a multi-disciplinary open access archive for the deposit and dissemination of scientific research documents, whether they are published or not. The documents may come from teaching and research institutions in France or abroad, or from public or private research centers.
L'archive ouverte pluridisciplinaire HAL, est destinée au dépôt et à la diffusion de documents scientifiques de niveau recherche, publiés ou non, émanant des établissements d'enseignement et de recherche français ou étrangers, des laboratoires publics ou privés. 


\section{Comment on « N-terminal Protein Tail Acts as Aggregation Protective Entropic Bristles : The SUMO}

\section{Case ॥}

Magalie Sénéchal, Jennifer Bouchenna, Jérôme Vicogne*, Oleg Melnyk*

Univ. Lille, CNRS, Inserm, CHU Lille, Institut Pasteur de Lille, U1019 - UMR 9017 - CIIL - Center for Infection and Immunity of Lille, F-59000 Lille, France.

In a paper published in 2014, ${ }^{1}$ Grana-Montes, R. et al. studied the secondary structure and aggregation of human small ubiquitin-like modifier 2 (SUMO-2) and proteins derived thereof. Like ubiquitin, SUMO are small proteins that are enzymatically attached to the target proteins through an isopeptidic bond linking the C-terminal glycine residue of SUMO to the side-chain amino group of surface exposed lysine residues. SUMO-2 is one of the five human SUMO paralogs identified so far and is frequently studied for being constitutively expressed in all eukaryotic cells, like SUMO-1 and SUMO-3.,3

The study of the role of SUMO-2 tail, i.e. the first 14 amino acid residues (Fig. 1A), in protecting SUMO2 from aggregation led the authors to analyse SUMO-2 and its truncated variant $\triangle \mathrm{Nt}$-SUMO-2 starting at residue 15 by circular dichroism (CD) in the far-UV region using $50 \mathrm{mM}$ phosphate buffer $(\mathrm{pH} 7)$. The authors found that the CD spectra of the two proteins are "essentially identical" (Fig. 2A in their article, ${ }^{1}$ which presents the ellipticity $\Theta$ in mdeg between 195 and $270 \mathrm{~nm}$ at $298 \mathrm{~K}$ ).

A)

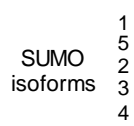

tail

core

B)

SUMO-2

Pdb 2N1W

SUMO core domain

$78 \mathrm{AA}$

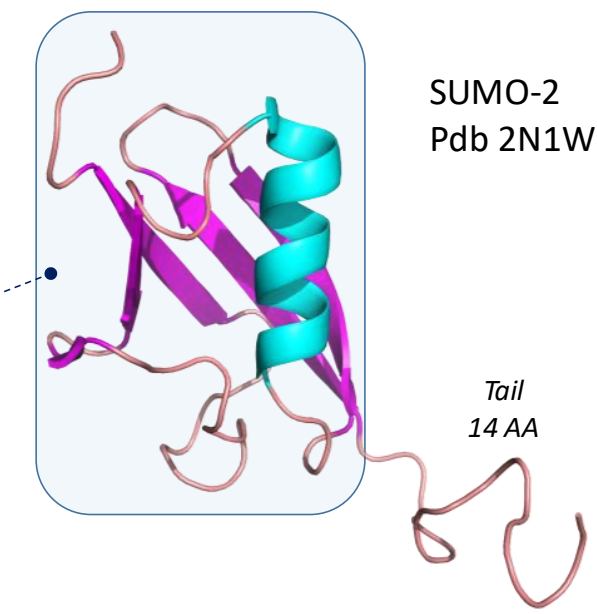


Figure 1. A) Protein sequences from human SUMO isoforms. Color background of amino acids corresponds to the chemical nature of the side chain (aromatic - yellow, acidic - red, basic - blue, nonpolar - orange, polar - green). See ref ${ }^{4}$ for more details. B) NMR structure of SUMO-2 showing the $\mathrm{N}$-terminal tail and the core domain ( $\left.\mathrm{pdb} 2 \mathrm{~N} 1 \mathrm{~W}^{5}\right)$.

Our recent studies ${ }^{4,6,7}$ on the stability and biochemical properties of SUMO proteins led us also to compare SUMO-2 (92 AA) and $\triangle \mathrm{Nt}-\mathrm{SUMO}-2$ (78 AA) by the same technique. The proteins were produced by chemical synthesis using the bis(2-sulfanylethyl)amido-mediated ligation of two unprotected peptide segments in water. ${ }^{8-12}$ Their homogeneity and identity was verified by UPLC-MS. ${ }^{4}$ The far-UV CD spectrum of SUMO-2 protein was similar to a commercially available SUMO-2 recombinant product. Synthetic SUMO-2 protein was also analyzed by SDS-PAGE using Coomassie blue R250 staining, by Western-blot using an anti-SUMO2/3 antibody and its functionality was verified by performing an enzymatic conjugation assay using RanGAP as target protein. Moreover, the assembly method was validated by the production of various functional conjugates including SUMO-2/3 dimers. ${ }^{4,6}$ Our data suggest that the far-UV CD spectra of SUMO-2 and $\triangle \mathrm{Nt}$-SUMO-2 are different when plotting the mean residue ellipticity $[\Theta]_{\text {MRW }}$ against the wavelength between 190 and $260 \mathrm{~nm}$ at 298 K. ${ }^{4}$ Note that the buffer used in our previous work $(10 \mathrm{mM} \text { sodium phosphate buffer, } \mathrm{pH} 7.2)^{4}$ or in the studies reported in this Comment (see later) for solubilizing the proteins is different from those used by Grana-Montes, R. et al. in their study.

Intrigued by this discrepancy, novel batches of SUMO- 2 and $\triangle \mathrm{Nt}-\mathrm{SUMO}-2$ proteins were produced. We produced also the 14 AA peptide corresponding to the tail. During our experiments, we noticed that $\Delta$ Nt-SUMO-2 had a limited solubility in phosphate buffer, which could be improved significantly by adding $50 \mathrm{mM} \mathrm{NaCl}$. To facilitate the $\mathrm{CD}$ analysis of the proteins, we used instead a sodium phosphate/NaF buffer that has the advantage of being more transparent to UV light below $200 \mathrm{~nm}$ and thus more appropriate for providing high quality far-UV CD spectra. ${ }^{13}$ SUMO-2, $\triangle N$ N-SUMO-2 and the tail peptide were analyzed by $C D$ by performing four independent experiments. The results expressed as $[\Theta]_{\text {MRW }}$ (mean $\pm 95 \%$ confidence limits) against the wavelength between 185 and $260 \mathrm{~nm}$ are presented in Fig. 2 . With these data, we confirm that the far-UV CD spectra of SUMO-2 and $\Delta \mathrm{Nt}-$ SUMO-2 are significantly different. The alpha-helical content (mean $\pm 95 \%$ confidence limits) of SUMO$2(15.7 \pm 0.47 \%, n=4)$ calculated using the empirical equation of Greenfield \& Fasman is significantly lower than those measured for $\Delta \mathrm{Nt}-\mathrm{SUMO}-2(17.5 \pm 0.23 \%, \mathrm{n}=4)$, a result which is in agreement with the data obtained after deconvoluting CD spectra using Dichroweb online server (see Supplementary Information). Moreover, the CD spectrum of SUMO-2 shows a minimum at $205 \mathrm{~nm}$, which is found at 
$208 \mathrm{~nm}$ in the spectrum of $\triangle \mathrm{Nt}$-SUMO-2 protein. The CD spectrum of the tail peptide shows that it is largely in a random coil conformation with a minimum at $198 \mathrm{~nm}$.

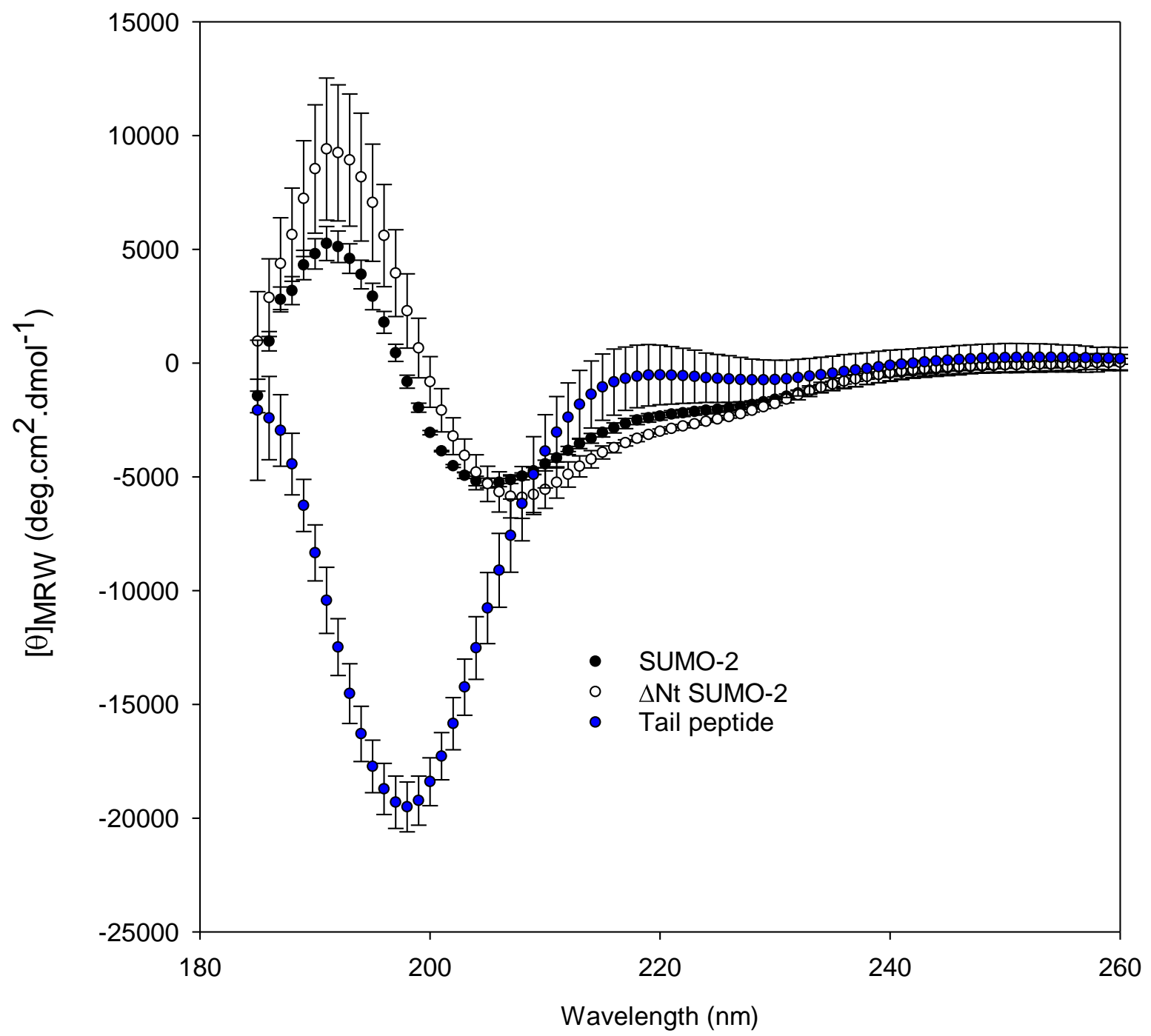

Figure 2. CD analysis of synthetic SUMO-2, $\triangle N \mathrm{Nt}-\mathrm{SUMO}-2$ and tail peptide. Conditions: $10 \mathrm{mM}$

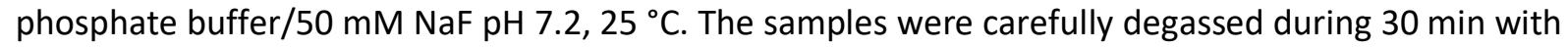
argon and immediately transferred under argon into the CD cuvette. Protein concentration was 10-20 $\mu \mathrm{M}$ for SUMO-2 and $\triangle \mathrm{Nt}$-SUMO-2 (see Supplementary Information). Tail peptide concentration was 100-230 $\mu \mathrm{M}$ (see Supplementary Information). The results expressed as $[\Theta]_{\text {MRW }}$ (mean $\pm 95 \%$ confidence limits) where obtained by performing four independent analyses. Full experimental details, $C D$ data and the data obtained after the deconvolution of CD spectra using Dichroweb online server can be found in the Supplementary Information files. 
As largely discussed in the literature, the tail of SUMO-2 protein is poorly structured ( $p d b 2 A W T,{ }^{14} p d b$ $2 \mathrm{~N} 1 \mathrm{~W}$ see Fig. $1 \mathrm{~B},{ }^{5}$ pdb $2 \mathrm{~N}^{1} \mathrm{E}^{15}$ ). In contrast, the core domain of SUMO-2 which corresponds to the sequence of $\Delta \mathrm{Nt}$-SUMO-2 adopts a typical ubiquitin fold, with an alpha-helix packed against a fourstranded beta-sheet (Fig. 1B). The far-UV CD spectrum of a protein can be represented by a linear combination of the spectra of its secondary structural elements, which include the disordered parts of the protein. ${ }^{16}$ Therefore, the CD spectra of SUMO-2 and $\triangle \mathrm{Nt}$-SUMO-2 are expected to be different in the light of the structural studies available for SUMO-2. Logically, the presence of the disordered tail in SUMO-2 lowers the alpha-helical content of the protein $(15.7 \pm 0.47 \%)$ compared to $\triangle \mathrm{Nt}$-SUMO-2 $(17.5 \pm 0.23 \%)$ and also explains the shift of $3 \mathrm{~nm}$ in the position of the minimum around $208 \mathrm{~nm}$.

In conclusion, the far-UV CD spectra of SUMO-2 and $\triangle \mathrm{Nt}$-SUMO-2 are significantly different. We provide a robust protocol for the far-UV CD analysis of these proteins as well as all the data as a Supplementary Excel file for those interested in the study of SUMO protein conformation.

\section{Acknowledgment}

We thank the Ministère de l'Enseignement Supérieur, de la Recherche et de l'Innovation for financial support (PhD fellowship to Jennifer Bouchenna).

\section{Supplementary Information Available}

Experimental procedure for $C D$ analyses can be found in the Supplementary PDF file. CD data and deconvolution results can be found in the Supplementary Excel file. Data source files (.txt format) for all analyses are also provided in a compressed folder.

The Supplementary Information is available free of charge on the ACS Publications website at DOI: \#\#\#\#\#\#\#\#.

\section{References}

(1) Grana-Montes, R.; Marinelli, P.; Reverter, D.; Ventura, S. N-Terminal Protein Tails Act as Aggregation Protective Entropic Bristles: The SUMO Case. Biomacromolecules 2014, 15, 11941203. 
(2) Matunis, M. J.; Coutavas, E.; Blobel, G. A Novel Ubiquitin-Like Modification Modulates the Partitioning of the Ran-GTPase-Activating Protein Rangap1 between the Cytosol and the Nuclear Pore Complex. J. Cell. Biol. 1996, 135, 1457-1470.

(3) Lapenta, V.; Chiurazzi, P.; van der Spek, P.; Pizzuti, A.; Hanaoka, F.; Brahe, C. SMT3A, a Human Homologue of the $S$. Cerevisiae Smt3 Gene, Maps to Chromosome 21qter and Defines a Novel Gene Family. Genomics 1997, 40, 362-366.

(4) Bouchenna, J.; Sénéchal, M.; Drobecq, D.; Stankovic-Valentin, N.; Vicogne, J.; Melnyk, O. The Role of the Conserved SUMO-2/3 Cysteine Residue on Domain Structure Investigated Using Protein Chemical Synthesis. Bioconjugate Chem. 2019, 30, 2684-2696.

(5) Naik, M. T., Naik, N., Shih, H., Huang, T., 2016. Solution structure of human SUMO2. DOI: 10.2210/pdb2N1W/pdb.

(6) Bouchenna, J.; Sénéchal, M.; Drobecq, H.; Vicogne, J.; Melnyk, O. Total Chemical Synthesis of All SUMO-2/3 Dimer Combinations. Bioconjugate Chem. 2019, 30, 2967-2973.

(7) Drobecq, H.; Boll, E.; Senechal, M.; Desmet, R.; Saliou, J. M.; Lacapere, J. J.; Mougel, A.; Vicogne, J.; Melnyk, O. A Central Cysteine Residue Is Essential for the Thermal Stability and Function of SUMO-1 Protein and SUMO-1 Peptide-Protein Conjugates. Bioconjugate Chem. 2016, 27, 1540-1546.

(8) Agouridas, V.; El Mahdi, O.; Diemer, V.; Cargoet, M.; Monbaliu, J.-C. M.; Melnyk, O. Native Chemical Ligation and Extended Methods. Mechanisms, Catalysis, Scope and Limitations. Chem. Rev. 2019, 12, 7328-7443.

(9) Melnyk, O.; Vicogne, J. Total Chemical Synthesis of SUMO Proteins. Tetrahedron Lett. 2016, 57, 4319-4324.

(10) Raibaut, L.; Ollivier, N.; Melnyk, O. Sequential Native Peptide Ligation Strategies for Total Chemical Protein Synthesis. Chem. Soc. Rev. 2012, 41, 7001-7015.

(11) Ollivier, N.; Dheur, J.; Mhidia, R.; Blanpain, A.; Melnyk, O. Bis(2-Sulfanylethyl)Amino Native Peptide Ligation. Org. Lett. 2010, 12, 5238-5241.

(12) Jennifer, B.; Magalie, S.; Hervé, D.; Jérôme, V.; Oleg, M. The Problem of Aspartimide Formation During Protein Chemical Synthesis Using SEA-Mediated Ligation. ChemRxiv 2019, No 10.26434/chemrxiv.11409417.v1.

(13) Kelly, S. M.; Jess, T. J.; Price, N. C. How to Study Proteins by Circular Dichroism. Biochim. Biophys. Acta 2005, 1751, 119-139.

(14) Chang, C. K.; Wang, Y. H.; Chung, T. L.; Chang, C. F.; Li, S. S. L.; Huang, T. H., 2006. DOI: 10.2210/pdb2AWT/pdb.

(15) Anamika; Spyracopoulos, L. Molecular Basis for Phosphorylation-Dependent SUMO Recognition by the DNA Repair Protein Rap80. J. Biol. Chem. 2016, 291, 4417-4428.

(16) Greenfield, N. J. Using Circular Dichroism Spectra to Estimate Protein Secondary Structure. Nat. Protoc. 2006, 1, 2876-2890. 
For Table of Contents Use Only

Comment on « N-terminal Protein Tail Acts as Aggregation Protective Entropic Bristles : The SUMO Case »

Magalie Sénéchal, Jennifer Bouchenna, Jérôme Vicogne*, Oleg Melnyk*

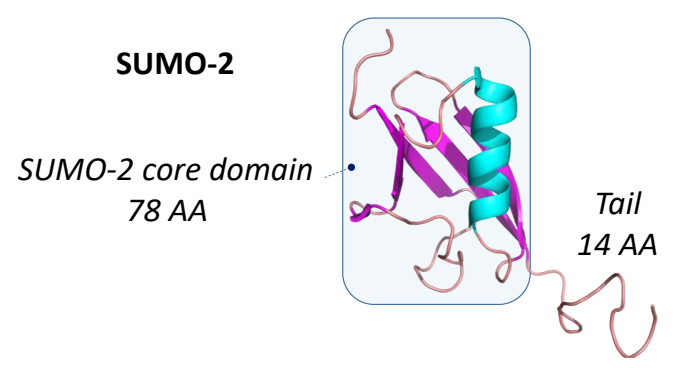

